\title{
ADOPTION AND IMPACTS OF NATURAL RESOURCE CONSERVATION IN ARSI ZONE, ETHIOPIA
}

\author{
Tamrat Gebiso Challa ${ }^{1}$ \\ ${ }^{1}$ Socioeconomics Research Directorate, Oromia Agricultural Research Institute, Asella, Ethiopia
}

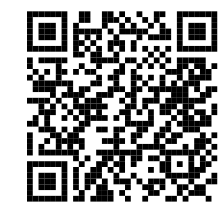

Received 28 June 2021

Accepted 12 July 2021

Published 31 July 2021

DOI 10.29121/

granthaalayah.v9.i7.2021.4060

Funding: This research received no specific grant from any funding agency in the public, commercial, or not-for-profit sectors.

Copyright: (C) 2021 The Author(s). This is an open access article distributed under the terms of the Creative Commons Attribution License, which permits unrestricted use, distribution, and reproduction in any medium, provided the original author and source are credited.

\section{ABSTRACT}

Land degradation in Ethiopia alone accounts for $8 \%$ of the global total degradation. The most serious problem concerning country's land resources, however, is the removal of fertile topsoil by water. Population pressure which results to intensive cultivation, overgrazing deforestation and inappropriate land use practices are the most serious cause of soil erosion in Ethiopia which is more severe in the highlands areas where, $85 \%$ of the human and $77 \%$ of livestock population are living and agriculture is intensive. To reverse the situation the government of Ethiopia designed policy and programs which are holistic and landscape wide approaches. Based on the strategies, different soil and water management programs have been implemented throughout the country and different practices were introduced to farmers as well for more than ten years. The central questions of this research were, whether farmers adopt these soil and water conservation practices; and if yes, do these soil and water conservation interventions have an impact in improving crop production in value per hectare and gross annual income of participating households? If yes, how much is the impact? Based on above objectives, the research was conducted in Arsi zone and data was collected from 202 respondents in representative districts. Both adopters and counterfactual respondents were included. Educational background of households, farming experiences, size of landholding, slop of plot, degree of vulnerability of the districts and extension contact significantly and positively affect adoption probability while land fragmentation was significant and negatively influencing adoption of soil and water conservation (SWC) activity. Though it was not statistically significant, SWC adoption has positive impact on productivity, gross production and income of the household. The average treatment effect on treated (ATT) was 6358.86 ETB of total household income which could be proxy for farm level productivity and 85.35 quintal of total annual farm production.

Keywords: Soil and water conservation, Ethiopia, Adoption, Impact, Propensity score matching 


\section{BACKGROUND AND JUSTIFICATION}

Reduction or losses of biological or economic productivity of land resulting from land use cover change or processes arise from anthropogenic activities, such as soil erosion caused by long-term deterioration of natural vegetation Mundia and Aniya (2006). This phenomenon of the land is becoming one of the most severe global problems of our times Nanpham et al. (2001) and Kertesz (2009)and this phenomenon affects $33 \%$ of the land surface; and has direct or indirect consequences for more than 2.5 billion people "Land Degradation Strategy" (2010). Around 40\% of world agricultural land is currently seriously degraded and soil erosion accounts for around $80 \%$ of this degradation Angima et al. (2003), Kessler and Stroosnijder (2010). In countries where agriculture and other natural resource bases are the main pillar for their economic development, the continuous depletion of resources is becoming a serious hazard Bruutrup and Zimmermann (2009) of which Sub-Saharan African countries are the most affected Berry et al. (2003).

Tekalign (2008) indicated that land degradation in Ethiopia alone accounts for $8 \%$ of the global total degradation which is huge compared to our land size in proportion to global land size. The most serious problem concerning country's land resources, however, is the removal of fertile topsoil by water. Osman and Sauerborn (2001) reported that an increase in population and consequent activities such as intensive cultivation, overgrazing by livestock, deforestation and inappropriate land use practices to satisfy its needs are the fundamental factors that exposed the Ethiopian soil to erosion. This is much more severe in the highlands where, $85 \%$ of the human and $77 \%$ of livestock population are living and agriculture is intensive Gete (2000). As estimates from national level studies indicate, more than 2 million ha of Ethiopia's highlands have been degraded beyond rehabilitation, and an additional 14 million hectares severely degraded, which is reflected in reduction of cereal yield to less than 1.2 tons per hectare in most of the highlands Fao/Wfp (2005). The comparative analysis report of a decade by Environmental Forest Development on the cost of land degradation also indicated that, the net amount of soil eroded in 1995 was 130 million metric tons and this has increased to 182 million metric tons in 2005 and the nutrient loss from lost soil in terms of phosphorus and nitrogen was 1.1 and 1.3 million metric tons, respectively. The monetary value of productivity loss, due to soil loss, also shows 639 and 766 million Birr in 1995 and 2005, respectively Efd (2010).

As a result of this extensive land degradation, which in turn is caused by various intermingled factors, soil productivity has been negatively affected and agricultural production has not been able to meet the basic food requirements of the growing population Hurni et al. (2016). To improve the situation, governments and development agencies have invested substantial resources in promoting soil conservation practices as part of efforts to improve environmental conditions and ensure sustainable and increased agricultural production Minale (2005), Menale et al. (2011). 
Studies conducted in different parts of the country indicted that the level of success in SWC activities was low. This low level was explained by factors like poor performance of the technologies themselves, policy and institutional deficiencies at different levels and other socioeconomic factors Lakew et al. (2005), Mitiku et al. (2006), Bekele et al. (2009), Menale et al. (2011). The interventions were primarily technology oriented and top-down with limited participation of the beneficiaries in decision making Berhanu et al. (2009). Such command-and-control type of interventions that have not been linked to the indigenous land conservation knowledge of the farmers as well as their local institutions, reduced the sense of responsibility over the area conserved Lakew et al. (2005). Most policies, programs and projects for sustainable land management were also designed without making a distinction between proximate and underlying causes which in turn forced the technologies to focus narrowly on structural measures to arrest soil erosion only, without fully considering the underlying causes of low soil productivity, socio-economic factors, and the need for tangible benefits to be attractive to poor farmers Berhanu et al. (2009). According to Mitiku et al. (2006), Berhanu et al. (2009) and others, even though many scholars raised different factors affecting the sustainability of conservation measures, the main shortcomings of conservation efforts in previous periods were largely rooted in a lack of understanding of the important interface between resource conservation and agriculture, and of the factors that motivate farmers to invest in sustainable land management over the long run.

In an effort to address these problems, the basic paradigm and approach to land and water conservation has evolved over time Bekele et al. (2009) and the Ethiopian government has changed its land management policy to more holistic and landscape wide approaches that go beyond resource conservation towards improved land husbandry and water management for beneficial conservation Reddy (2005), Kerr et al. (2007). Given this policy, different soil and water management programs have been implemented throughout the country and different practices were introduced to farmers as well. The central issue is thus, whether farmers adopt these soil and water conservation practices; and if yes, do these soil and water conservation interventions have an impact in improving crop production in value per hectare and gross annual income of participating households? If yes, how much is the impact? Policy makers and development practitioners need to know the empirical output of these questions to decide about their future approaches.

With the above-mentioned context of policy endorsed and its objectives this study was carried out in Arsi Zone of Oromia Regional State, Ethiopia where various conservation programs have been executed to improve the livelihoods of most vulnerable households through value adding and natural resources management (NRM)-based income generation at household level. Therefore, this research was initiated with the following objectives to: 1) assess the impacts of the natural resource conservation practices on yields and farmers' income; 2) assess community participation and gender roles in natural resource conservation activities; 3 ) assess community 
perception towards the ongoing natural resource conservation interventions; and 4) identify constraints and opportunities on SWC practices in the study area.

\section{RESEARCH METHODOLOGY}

\subsection{DESCRIPTION OF STUDY AREAS}

This study was conducted in five districts of Arsi zone located in south-east region of Oromia in Ethiopia. Arsi zone lies between $6^{0} 45^{\prime} \mathrm{N}$ to $8^{0} 58^{\prime} \mathrm{N}$ and $38^{0} 32 \mathrm{E}$ to $40^{\circ} 50^{\prime} \mathrm{E}$. Arsi is bordered on the south by Bale, on the southwest by the West Arsi Zone, on the northwest by East Shewa, and on the east by West Hararghe. All the three traditionally classified agro-ecologies which are highland (dega/beddaa), mid highlands (wainadega/bede-dere) and lowlands (kola/gammojjii) are found in Arsi zone. Given its diversified agro-ecologies which range from lowest point of up to 805masl in Seru district of Wabe gorge to highest point of altitude 4195masl which is found in Kaka mount (BOFED, 2011), the zone has also diversified production system which can be classified into two broad categories as crop-livestock mixed farming and the pastoral/agro-pastoral farming system. However, as it was indicated in A. Tamrat and Ashebir (2019), there are around seven sub-farming systems which are: barley-root crops, wheat-teff, large seeded cereals maize-sorghum, rain fed coffee-khat (Chat)-tree, irrigation, agro-pastoral and peri-urban sub-clustered farming systems.

According to A. Tamrat and Ashebir (2019), the three dominant soil types in Arsi zone are: the Chromic and Pellic Vertisols having characteristics of water holding and heaviness for plowing during rainy seasons due to high clay content that covers about $30 \%$ of the zone's soil type; the Cambisols (accounts for $23 \%$ of total soil type) dominantly occur on the steep slopes and are often shallow or have many rock outcrops and those developed on gentler slopes, however, have good base saturation and fertility and can be used for agricultural purposes; the third is Luvisols which is good for agriculture with base saturation and weatherable minerals and dominant on the high land parts covering about $13 \%$ area of the zone. The rest of the soil types are Lithosols which is another soil type having good base saturation and fertility status and constituting about $6 \%$ of total and Fluvisols, constitutes about $2 \%$ of the total soil groups' coverage, and found in the lowland parts of Gololcha, Merti \& Ziway-Dugda districts.

The activity of soil and water management is performed every year at the end of main season's agricultural activities i.e., after harvesting the crops grown during main season usually in the month of January for one to two months. This activity is assisted by trained development agents (DAs) which are assigned to each Kebele (PA). Recently, some active farmers (model and can read and write) are also gathered at district level from each PA and practical trainings of trainers (TOT) are being given and the trained farmers are responsible for both training and leading the soil and water conservation activity in their PA in collaboration with DAs. 


\subsection{SAMPLING TECHNIQUE AND SAMPLE SIZE}

A two-stage sampling technique was employed. However, before sampling, the zone was stratified into three based on traditional agro-ecological classification (highland, mid highland and low land). From each stratum, districts which are highly vulnerable to natural calamities specially erosion and landslides were identified after discussion with zonal natural resource conservation team. These districts are known for relatively high intervention of soil and water conservation practices. Then at the first stage from each identified strata a total of five representative sample districts were selected based on above criteria (agro-ecological base and availability of soil and water conservation practices). As a result, Lemu-bilbilo and Inkolo-Wabe were selected from highland districts and Aseko from mid-highlands while Seru and Merti were selected from lowland districts. The sample size from each district was based on proportionality to areas of intervention in soil and water conservation activities. Therefore, at the second stage based on this proportionality, a total of nine peasant associations (PAs) were selected. Accordingly, two PAs from each Seru, Inkolowabe, Merti and Aseko districts and one PA from Lemubilbilo district (total nine) were selected. Finally, 66 respondents from highlands, 44 from mid highlands and 92 from lowland were randomly drawn to make the total sample size of 202 .

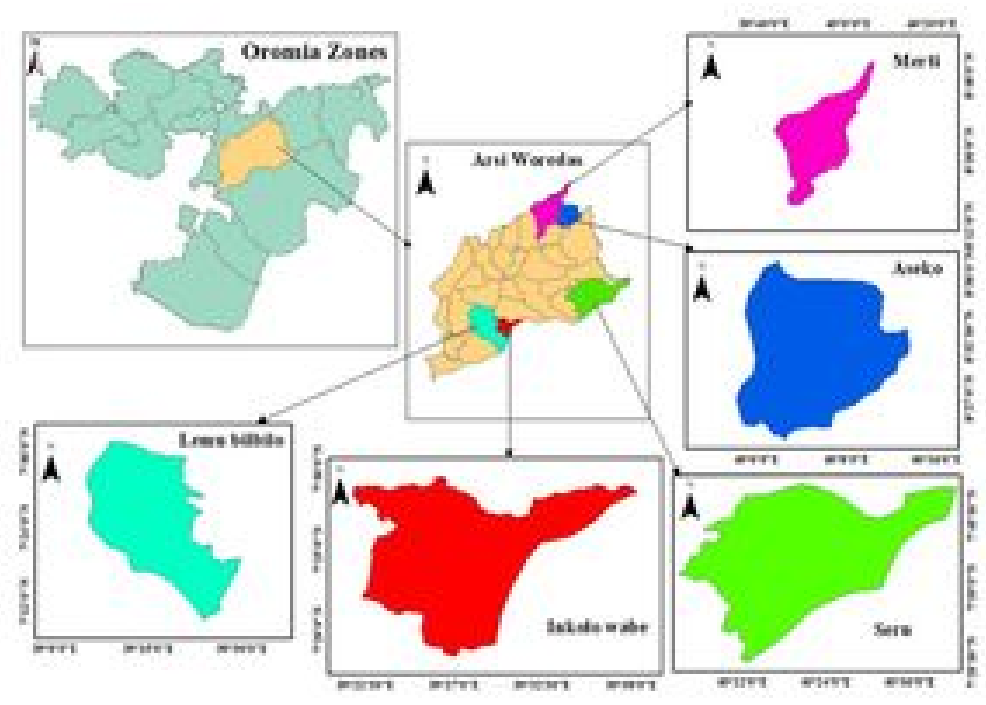

Figure 1 Map of the study districts

\subsection{SOURCE AND TYPE OF DATA}

Both primary and secondary data were collected from farmers, DAs, districts and zonal level soil and water conservation experts. Both beneficiaries (adopters) of soil and water conservation practices and non-beneficiaries (non-adopters) (technically known as counterfactual) farmers were interviewed using structured questionnaire. 
Published and unpublished secondary data were collected from zonal and districts' reports and online sources. Data collected include socio-economic aspects, crop production, soils and land use change and sustainable land management, types of soil and water conservation practices, and land ownership and etc. Survey instrument used for data collection is attached for further reference in appendix part (Appendix V).

\subsection{METHODS OF DATA ANALYSIS}

Both descriptive and inferential and econometric analyses were employed to meet the specific objectives of this study. Descriptive and inferential statistics like frequency, mean and tabulation were used while from econometric model's propensity score matching (PSM) was used to analyze impact of adoption of soil and water conservation activities on income and yields of selected cereal crops in the study area. The PSM technique enables us to extract from the sample of nonparticipating (nonadopter) households a set of matching households that look like the participating (adopter) households in all relevant pre intervention characteristics. In our study participation in soil and water conservation activities (adoption of one or more of soil and water conservation practices listed) is treatment and those participants are treatment groups while non-participant group members are control groups. This study attempts to estimate the average impact of treatment on treated (ATT). Bryson et al. (2002) indicated that ATT refers to mean impact of the program (adoption) on individuals who actually participated.

\subsubsection{ESTIMATION OF PROPENSITY SCORE}

The first step in estimating the treatment effect is to estimate the propensity score. In this study logit model was used to estimate propensity scores using a composite of pre-intervention characteristics of the sampled households and matching was performed using propensity scores of each observation. In estimating the logit model, the dependent variable for participation which takes the value of 1 if a household practiced soil and water conservation on his/her own plot and 0 otherwise. Mathematically it can be explained as follows:

$$
p i=\frac{e^{z i}}{1+e^{z i}}
$$

Where, Pi is the probability of participation (adopting soil and water conservation practices),

$$
z i=a o+\sum_{i=1}^{n} a i X i
$$

Where, $\mathrm{i}=1,2,3,--\cdot, \mathrm{n}$

$$
\begin{aligned}
& \mathrm{a}_{0}=\text { intercept } \\
& \mathrm{a}_{i}=\text { regression coefficients to be estimated }
\end{aligned}
$$


$\mathrm{U}_{i}=$ a disturbance term

$1-\mathrm{Pi} \frac{1}{1+e^{z i}}$ is the probability of a household belonging to out of the program (probability of non-adopting soil and water conservation practices)

Heckman et al. (1998) states that in social science research where experimental research is difficult due to different reasons, impact evaluation studies are problematic due to the presence of selection bias which could be arise mainly from nonrandom location of the intervention and the nonrandom selection of participant households. Bernard et al. (2010) identifies three sources of potential biases. The first potential source of bias is the observable characteristics of the participants (such as geographic remoteness, or a household's physical and human capital stock) which may significantly differ from nonparticipants at community or household level and this may have direct effect on outcome of the interest (households' income and farm productivity in our cases). Secondly, the difference arises due to unobservable community level characteristic such as the existence of intervention may be in part driven by particularly dynamic local leaders at community level or at the household level, a household's expected benefits, its entrepreneurial spirit, or its relationship with other program/project may significantly influence behavior. Thirdly, externalities (spillover effect) exerted by project/intervention on nonparticipants could be source of bias in a given research activity of impact study.

As a result of one or more of these abovementioned potential sources of bias, the difference between the participants and control group (in our case the difference in households' income and farm productivity between SWC adopters and nonadopter) may either totally or partially, reflect initial differences between the two groups rather than the effects of adopting the SWC practices under consideration.

\subsubsection{CHOICE OF MATCHING ALGORITHM}

Naturally, estimation of the propensity score not enough to estimate the ATT of interest due to the fact that propensity score is a continuous variable and the probability of observing two units with exactly the same propensity score is zero. To overcome this problem, there are different matching algorithms which have been proposed. Among others, the most widely applied matching estimators are Nearest Neighbor (NN) Matching, Caliper Matching and Kernel matching. As it was explained by Caliendo and Kopeinig (2008), these methods differ from each other with respect to the way they select the control units that are matched to the treated, and with respect to the weights they attribute to the selected controls when estimating the counterfactual outcome of the treated. However, they all provide consistent estimates of the ATT under the CIA and the overlap condition. The choice should be guided in part by what the distribution of scores in the comparison and treatment samples looks like. In this case matching algorithm, which gives larger common supports was selected. 


\subsubsection{OVERLAP AND COMMON SUPPORT}

According to Bryson et al. (2002) imposing a common support condition ensures that any combination of characteristics observed in the treatment group can also be observed among the control group. After identification of common support, it requires deleting all observations out of the overlapping region, whose propensity scores are smaller than the minimum and larger than the maximum, of the treatment and control groups respectively Caliendo and Kopeinig (2008).

\subsubsection{TESTING THE MATCHING QUALITY}

As it was justified by Caliendo and Kopeinig (2008), since conditioning is not on all covariates but on the propensity score, matching quality has to be checked if the matching procedure is able to balance the distribution of the relevant variables in the control and treatment group. Standard bias, t-test, joint-significance and pseudo- $\mathrm{R}^{2}$ approaches are applied in covariate balancing (i.e., the equality of the means on the scores and all the covariates) between treated and non-treated individuals.

\subsubsection{ESTIMATING THE AVERAGE TREATMENT EFFECT ON THE TREATED (ATET}

For random experiments average treatment effect (ATE) which is the difference between the outcome of treated and control groups can be fine but in observational studies, it can be biased if treated and control observations are not similar. Therefore, another option to treat this problem is needed which is the way to find average treatment effect on treated (ATET). ATET is the difference between outcomes of the treated and outcomes of the treated if they had not been treated.

$$
A T E T=E(\triangle D=1)=E(Y 1 X, D=1)-E(Y 0 X, D=1)
$$

The second term is not observable hence need to be estimated and it is why we need the propensity score matching methods. After matching on propensity scores, we can compare the outcomes for treated and control observations. Then the average treatment effect on treated (ATET) will become:

$$
A T E T=E(\triangle P(X), D=1)=E(Y 1 P(X), D=1)-E(Y 0 P(X), D=0)
$$

For this above condition to hold true there are some assumptions as discussed by Heckman et al. (1998):

Partial equilibrium characteristic (no general equilibrium effect) condition which is the assumption that there are no program spillover effects;

Conditional independence assumption: for random experiments, the outcomes are independent of treatment Wooldridge (2002). This is simply an assumption for the treatment variable to be exogenous. 
Unconfoundedness Assumption: it is the conditional independence of the control group outcome and treatment and it is the weaker assumption than the conditional independence assumption.

$\mathrm{Y} 0 \perp \mathrm{D} \mid \mathrm{X}$

Matching or overlap assumption: it is an assumption of that for each value of $\mathrm{X}$, there are both treated and control observation. That is for each treated observation; there is a matched control observation with similar $\mathrm{x}$.

$0<\operatorname{Prob}(\mathrm{D}=1 / \mathrm{X})<1$

Based on Keele (2010), sensitivity analysis should be conducted to check the robustness of the estimation (whether there were hidden biases affected the estimated ATT or not) for an outcome indicator which shows significance. However, in our case, even though "rbounds" bounding approach proposed by Rosenbaum (2002) was proposed, since ATT matched outcome variables estimations did not show significance ( $t$-test for ATT was not significant), sensitivity analysis was not necessary.

On the basis of the various studies reviewed, it was hypothesized that both farmer's participation in the soil and water conservation program and maximization of their crop and gross income and farm output are influenced by the combined effect of a number of factors. Thus, those specific hypotheses set for the selected variables and their prior expectations are described as follows:

1. Sex (dummy $1=$ male and o otherwise): being male is expected to have positive effect

2. Education (continuous in years of schooling): expected to have positive effect

3. Experience in farming (continuous and measured in year): expected to have positive effect

4. Family labor (continuous and measured in man-equivalent): expected to have positive effect

5. Landholding (continuous and measured in hectare): expected to have positive effect

6. Fragmentation (continuous \& measured in number of plots): has expected negative effect

7. TLU continuous and measured in tropical livestock): expected to have positive effect

8. Credit access: (dummy 1=yes) expected to have positive effect

9. Slope category: (categorical plain, gentle ....) sloppier is expected to have positive effect

10. District category (categorical: the more vulnerable expected to have positive effect

11. Cooperative distance (continuous measured in $\mathrm{km}$ ) expected to negative sign

12. Perceived Erosion (dummy 1=yes if the farmer perceived that his/her parcel is vulnerable to erosion and expected to positive sign) 
13. DA contact (continuous number of DA contacts per month) and expected to positive sign

\section{RESULT AND DISCUSSION}

\subsection{DEMOGRAPHIC AND SOCIOECONOMIC CHARACTERISTICS OF THE RESPONDENTS}

Result of the survey (Table 1 ) revealed that around 30 percent of the households' heads were illiterate while around 69 percent were literate. For those literate groups (Table 2 ) the mean year of schooling was 5.75 years with 2 and 12 years of minimum and maximum values respectively. The mean family size of the household was 7.5 persons with maximum of 35 family members. Each household has about 5 economically active (family member with working age of between 10 years and 64 years) family members. The mean farming experience of household head was around 23 years. The mean age of household head which are in active working group were around 40 years (Table 2 ). Only 4 percent of the household were female headed while the rest 96 percent were male headed. The man-equivalent family labor was 3.03 and 3.28 for adopters and non-adopters respectively. Soil and water conservation adopter household heads have statistically significant (at 99\% and 95\% respectively) educational background and farming experience. Similarly, adopters have more extension contact compared to non-adopter groups ( $t$-value significant at 99 percent) while dependency ratio for non-adopters is higher with significant t-value at 95 percent.

\begin{tabular}{cccc}
\hline \multicolumn{2}{l}{ Table 1 Household Demographic Characteristics } & & \\
\hline Variable Description & Category & N & Percent \\
Educational background of & Illiterate & 60 & 29.70 \\
HHH & Read and write & 2 & 1.00 \\
\hline Informal (religious) school & 1 & 0.5 \\
Marital status of household & Literate & 139 & 68.80 \\
head & Single & 2 & 1.00 \\
& Married & 197 & 97.500 \\
\hline Household head Sex & Divorce & 1 & 0.5 \\
& Widowed & 2 & 1.00 \\
\hline
\end{tabular}

Source: own survey data, 2019 


\begin{tabular}{|c|c|c|c|c|c|}
\hline \multirow[b]{2}{*}{ Description } & \multicolumn{3}{|c|}{ Mean } & \multirow[b]{2}{*}{ t-values } & \multirow[b]{2}{*}{ Sig. } \\
\hline & Adopter & $\begin{array}{c}\text { Non- } \\
\text { Adopter }\end{array}$ & Total & & \\
\hline Education & 6.0086 & 3.6744 & 3.96 & $5.79 * * *$ & 0.000 \\
\hline $\begin{array}{c}\text { Farming } \\
\text { experience }\end{array}$ & 24.62 & 20.02 & 22.75 & $2.76^{* * *}$ & 0.006 \\
\hline Family size & 7.39 & 7.63 & 7.5 & -0.426 & 0.67 \\
\hline $\begin{array}{l}\text { Family labor } \\
\text { (man-equ.) }\end{array}$ & 3.04 & 3.28 & 3.14 & -0.956 & 0.34 \\
\hline $\begin{array}{l}\text { Landholding } \\
\text { (ha) }\end{array}$ & 2.71 & 1.34 & 1.43 & 1.76 & 0.079 \\
\hline $\begin{array}{l}\text { Farm frag- } \\
\text { mentation }\end{array}$ & 2.60 & 2.35 & 2.50 & 1.22 & 0.22 \\
\hline $\begin{array}{l}\text { Gross } \\
\text { production } \\
\text { (qt) }\end{array}$ & 114.62 & 26.38 & 77.06 & 0.88 & 0.379 \\
\hline Yield (qt/ha) & 82.43 & 28.39 & 75.10 & 1.07 & 0.286 \\
\hline $\begin{array}{l}\text { Livestock } \\
\text { possession } \\
\text { (TLU) }\end{array}$ & 5.29 & 4.61 & 5.00 & 1.10 & 0.272 \\
\hline $\begin{array}{l}\text { Total income } \\
\text { (ETB) }\end{array}$ & 31772.41 & 23196.19 & 28121.15 & 1.61 & 0.109 \\
\hline $\begin{array}{c}\text { Extension } \\
\text { contact }\end{array}$ & 3.28 & 2.28 & 0.54 & $4.39^{* * *}$ & 0.000 \\
\hline $\begin{array}{l}\text { Distance to } \\
\text { FTC }(\mathrm{km})\end{array}$ & 2.65 & 2.37 & 2.53 & 0.71 & 0.481 \\
\hline $\begin{array}{c}\text { Distance to } \\
\text { main road } \\
(\mathrm{km})\end{array}$ & 3.80 & 3.23 & 3.56 & 0.77 & 0.443 \\
\hline $\begin{array}{c}\text { Distance to } \\
\text { cooperative } \\
(\mathrm{km})\end{array}$ & 2.43 & 2.01 & 2.25 & 1.02 & 0.306 \\
\hline
\end{tabular}

Source: own survey data, 2019

\subsection{MAIN ECONOMIC ACTIVITIES AND INCOME SOURCES OF THE HOUSEHOLDS}

The main production system of the zone is crop-livestock mixed farming with crop production as the main household income source and the livestock sector is mainly used as draught power sources and supplementary income source G. Tamrat (2018). The survey result revealed that around 95 percent of the respondents responded that grain crop production is the main source of their households' income source followed by vegetable production, khat (chat) and cattle production responded by around 17, 16 and 14 percent of respondents. Major crops produced in the areas are wheat and barley in the highlands and mid-highland areas and maize, teff and sorghum in lowlands and mid highlands. Wheat is among the widely produced crops in the study area being grown by around 44 percent of respondents and followed by maize and 
barley each produced by 39.11 and 37.13 percent respectively. The result is also similar with previous research output by A. Tamrat and Ashebir (2019). Livestock possession in tropical livestock unit (TLU), computed based on appendix II, was 5.29 and 4.60 for adopters and non-adopters respectively while on average each respondent possesses around 5(SD of 5) TLU.

\subsection{CONSTRAINTS AND FARMERS' PERCEPTION IN SOIL AND WATER CONSERVATION ACTIVITIES}

\begin{tabular}{|c|c|c|c|}
\hline Variable & Description & $\mathbf{N}$ & Percent \\
\hline $\begin{array}{l}\text { Perceived erosion as a } \\
\text { production problem }\end{array}$ & Yes & 164 & 81.19 \\
\hline \multirow[t]{3}{*}{ Erosion Severity level } & Very severe & 37 & 22.56 \\
\hline & Severe & 63 & 38.41 \\
\hline & Less severe & 64 & 39.02 \\
\hline \multirow[t]{10}{*}{ Cause of erosion } & Deforestation & 156 & 95.12 \\
\hline & Poor agricultural practices & 135 & 82.32 \\
\hline & Over cultivation & 120 & 73.17 \\
\hline & Cultivation of steeply sloped lands & 157 & 95.73 \\
\hline & Excessive rainfall & 109 & 66.46 \\
\hline & Soil erosion & 164 & 81.19 \\
\hline & Limited use of fertilizer & 116 & 57.43 \\
\hline & Continuous cultivation & 137 & 67.82 \\
\hline & Lack of conservation practices & 165 & 81.68 \\
\hline & Lack of fallowing & 114 & 56.44 \\
\hline \multirow{8}{*}{$\begin{array}{l}\text { Consequences of } \\
\text { erosion: }\end{array}$} & Decline in land productivity & 180 & 89.11 \\
\hline & Soil fertility decline & 174 & 86.14 \\
\hline & Soil depth reduced & 99 & 49.01 \\
\hline & Change in crop type & 94 & 46.53 \\
\hline & Difficulty in land preparation & 80 & 39.60 \\
\hline & Gully and sandy soil formation & 77 & 38.12 \\
\hline & Soil water holding capacity decline & 71 & 35.15 \\
\hline & Abandonment of land from production & 53 & 26.24 \\
\hline
\end{tabular}

Source: own survey data, 2019

About 81 percent of the farmers in the study area perceived soil erosion as one of the main production constraints (Table 3 ). Out of those respondents who perceived soil erosion as problem, 29.27 percent of them ranked the problem as very severe, 37.8 percent as severe and 32.93 percent of them ranked it as less severe. Expansion of cultivation to marginalized lands, deforestation and poor agricultural practices were ranked from first to third main causes of soil erosion by the respondents. Lack of conservation practices, soil erosion, continuous cultivation and limited use of chemical fertilizer were mentioned as main cause of loss of soil fertility 
in the study area. As it is perceived by the respondent farmers, about 89,86 and 49 percent of them responded that decline in land productivity, decline in soil fertility and reduced soil depth were the main consequences of soil erosion in the study area. Some 47 percent of the farmers also responded that they changed type of crops they produce due to soil erosion they faced.

\subsection{SOIL AND WATER CONSERVATION PRACTICES IN ARSI ZONE}

Table 4 Soil and water conservation Adoption status and conservation types

\begin{tabular}{cccc}
\hline Variable description & Categories & N & Percent \\
\hline $\begin{array}{c}\text { Soil and water } \\
\text { conservation: }\end{array}$ & Adopter & 116 & 57.40 \\
& Non-Adopter & 86 & 42.6 \\
\hline Types of SWC practices: & Traditional & 38 & 32.76 \\
& Improved & 76 & 65.52 \\
\hline Types of SWC practices: & Both & 2 & 1.72 \\
& Stone bund & 42 & 36.21 \\
& Soil bund & 29 & 25.00 \\
& Stone faced soil bund & 9 & 7.76 \\
& Fanya juu & 9 & 7.76 \\
& Cut-off drain & 5 & 4.31 \\
& Check-dam & 3 & 2.59 \\
& Terracing & 25 & 21.55 \\
& Contour plowing & 17 & 14.66 \\
\hline
\end{tabular}

**traditional type of soil and water conservation (SWC) is type of conservation done by farmers themselves without any training and guidance from development agents or other bodies while improved type is done under training, guidance and supervision from development agents.

According to the result (Table 4) out of total respondents' 57.4 percent were adopter of one or more type of soil and water conservation structures while 42.6 percent were non-adopters. The result also revealed that around 66 percent of the soil and water conservation practices implemented by the respondents are improved while around 33 percent was traditional and some 1.7 percent uses both traditional and improved practices. Majority of adopters which are 36.21, 25.00 and 21.55 percent are using improved types of stone bunds, soil bunds and terracing respectively while the rest of respondents are using contour plowing (14.66\%), stone faced bund and fanya-juu (7.76\% each), cut-off drain (4.31\%), check-dam (2.59\%) and grassstrip (0.86). Mean year of adoption (since a respondent started using SWC practices) was 3.30 years with minimum and maximum value of 1 and 10 years respectively. As result from table 5 revealed, the mean area of plots covered by stone bund, soil bund and terraces were 9.05-, 5.94- and 2.60-meter squares. The result shows that stone bund and soil bunds are the most preferred structures (Table 5 ). 
Table 5 Area of land covered by different types of SWC structures

\begin{tabular}{|ccccc}
\hline Variable description & $\mathbf{N}$ & Mean & StD & SE. Mean \\
\hline Area of stone bund developed in meter square & 116 & 9.05 & 15.35 & 1.43 \\
\hline Area of soil bund developed in meter square & 116 & 5.94 & 13.47 & 1.25 \\
\hline $\begin{array}{c}\text { Area of cut off-drain developed in meter } \\
\text { square }\end{array}$ & 116 & .47 & 4.66 & 0.46 \\
Area of check dam developed in meter square & 116 & 0.09 & 0.93 & 0.09 \\
Area of terraces developed in meter square & 116 & 2.60 & 6.23 & 0.58 \\
Area of fanayjuu developed in meter square & 116 & 0.35 & 2.84 & 0.26 \\
\hline Year of adoption & 116 & 3.30 & 2.96 & 0.28 \\
\hline
\end{tabular}

Source: own survey data, 2019

According to the survey result from perception and practical challenges farmers faced in implementing different types of SWC activities, stone bund, terrace and soil bund were mentioned as laborious, difficult in implementation and create difficulties to turn oxen during plowing (Table 6 ).

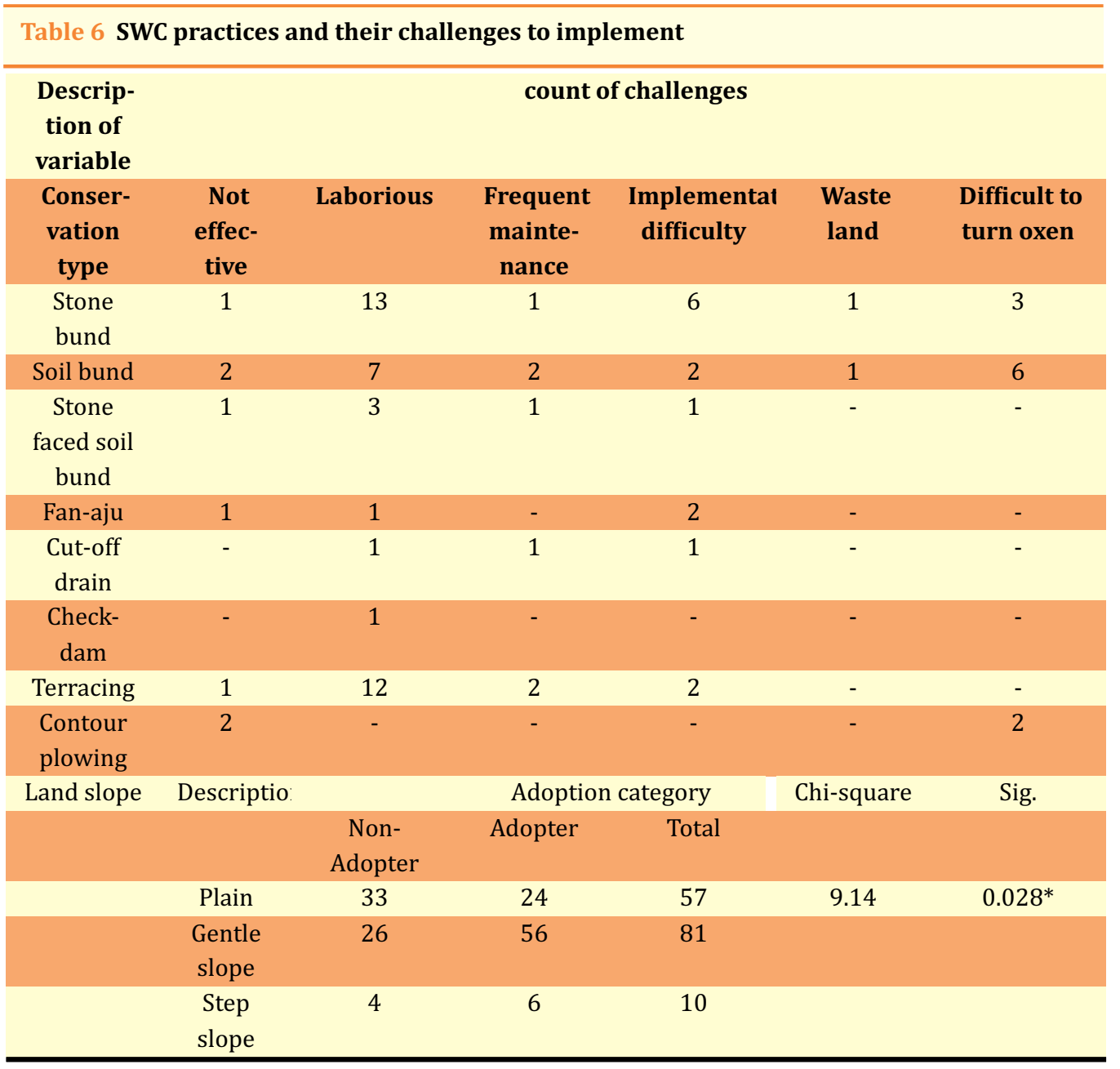




\begin{tabular}{cccc}
\hline & \multicolumn{3}{c}{ Table 6 continued } \\
\hline Both & 23 & 31 & 54 \\
plain & & & \\
and & & & \\
gentle & & & \\
slope & & & \\
\hline
\end{tabular}

Source: own survey data, 2019

\subsection{COMMUNITY PARTICIPATION AND GENDER ROLE IN SOIL AND WATER CONSERVATION ACTIVITIES}

Most of the SWC structures and activities are conducted by community campaign. Out of adopter farmers who have different conservation practices on their own plots, only 23.28 percent have practiced different SWC activities on their own farmlands while the rest of the adopters' of SWC activities were conducted by community campaign.

\begin{tabular}{|c|c|c|c|}
\hline Variable & Description & $\mathbf{N}$ & Percent \\
\hline \multirow[t]{2}{*}{ Participate of SWC campaign: } & Male & 192 & 98.97 \\
\hline & Female & 8 & 4.00 \\
\hline $\begin{array}{c}\text { Participate on project based SWC } \\
\text { activities }\end{array}$ & Yes & 42 & 20.80 \\
\hline \multirow[t]{3}{*}{ Your participation by type of land: } & Communal & 17 & 8.40 \\
\hline & Private & 93 & 46.00 \\
\hline & Both & 92 & 45.50 \\
\hline \multirow[t]{5}{*}{ Who participate on SWC campaigns? } & Husband & 136 & 67.3 \\
\hline & Wife & 3 & 1.5 \\
\hline & Boys & 4 & 2.00 \\
\hline & Hired labor & 1 & 0.50 \\
\hline & Husband and/or wife & 58 & 28.7 \\
\hline $\begin{array}{c}\text { Presence of area closure in your } \\
\text { areas }\end{array}$ & Yes & 131 & 64.9 \\
\hline If it is rehabilitated (Yes) & Yes & $126($ of131) & 96.18 \\
\hline $\begin{array}{l}\text { Get water spring due to its } \\
\text { rehabilitation }\end{array}$ & Yes & $15(131)$ & 11.45 \\
\hline $\begin{array}{l}\text { Use grass for livestock from } \\
\text { rehabilitated area }\end{array}$ & Yes & $80(131)$ & 61.10 \\
\hline Beekeeping in area closure & Yes & 4 & 3.05 \\
\hline $\begin{array}{l}\text { SWC has impact on your income and } \\
\text { productivity }\end{array}$ & Yes & 186 & 92.10 \\
\hline
\end{tabular}

Source: own survey data, 2019

As it is expected since work of soil and water conservation is a top-down planned campaign from government body, every member of a PA has no choice other than participating in the campaign. Accordingly, almost all respondents have participated on SWC activities campaign by order from the government every year. According 
to the result from Table $7,20.80$ percent of the respondents have participated on project based SWC activities. The projects around are safety net program and Malkawakena watershed development project that initiated by Ethiopian Electric Power Authority in Lemu-bilbilo district to protect electric generating dam. The safety net programs are implemented in the three districts Seru, Aseko and Merti where there was problem of food self-sufficiency due to drought and soil erosion. The inception period of safety net project varies from 1997 to 2010. The Melka Wakena project is a newly initiated project in 2018. In most cases, even though there is beginning of watershed development projects there is problem of materializing the activity on the ground and it is mostly a touch and release activity.

Most of the activities of SWC were done on private (individuals') land and accordingly, 46 percent and 8.40 percent of the respondents have participated on individuals and communal lands respectively while 45.5 percent of them participated in both communal and individuals land conservation activities. In most cases either husbands or wives were involved in SWC activities household level. Result from (Table 7 ) revealed that 67.3 percent of the respondents answered that only husbands participated while 28.7 percent replied that either husband or wife were involved on the campaign.

\subsection{IMPACTS OF SOIL AND WATER CONSERVATION PRACTICES ON YIELDS AND HOUSEHOLDS' INCOME}

Around 65 percent of the respondents indicated that there was area closure around them and some started realization of some benefits from the rehabilitated areas. From the assessment on their perception and benefits that are realized so far, 11.45 percent of respondents indicated that they were getting re-developed spring water from area closures, while 61.10 percent were using grass from area closure and 3.05 percent of them were benefiting from beekeeping activity in rehabilitated areas. In general, around 92 percent of the total sample perceived that the activity of SWC had a positive impact on their household income and farm productivity (Table 7 ).

\subsection{CONSTRAINTS AND OPPORTUNITIES IN SOIL AND WATER CONSERVATION PRACTICES IN ARSI ZONE}

With all its limitation the government led SWC campaign has great impact in awareness creation about the negative impact of deforestation, mismanagement of farmlands, cultivation of marginal lands and other kinds of misuse in natural resources. Even though some of them were being solved since two to three years (joint planning and training started), during the beginning of the campaign, inadequate training, the non-participatory nature of planning stage and absence of structure construction materials to implement some type of conservation structures like check and seedlings of conservation trees or grasses were the major challenges to implement and sustain the SWC activities (Table 8 ). About 42 percent of the respondents reported that absence of practical accountability after conservation activities were 
done was the main challenge in conservation activity. The free grazing practices of livestock during winter (Ethiopian Summer) season is the remaining problem in devastating all the structures that were constructed by the campaign and it hardly lasts for a year.

\section{Table 8 Drawbacks of SWC campaigns}

\begin{tabular}{ccc}
\hline Description & N & Percent \\
\hline No sufficient training & 35 & 17.30 \\
\hline No material/seedlings to cover the constructed structure & 33 & 16.30 \\
We do not participate on planning & 12 & 5.90 \\
\hline No accountability after work & 84 & 41.60 \\
\hline
\end{tabular}

Source: own survey data, 2019

\subsection{RESULTS OF ECONOMETRIC ANALYSIS}

Prior to proceeding to estimation using logistic regression model, different tests were conducted to confirm whether the data fits to the model. Among these HosmerLemeshow test was conducted to check if the data fit to our model. The chi-square value of 10.60 which is insignificant ( $p$-value=0. 2253) shows our data fit to logit model. To check for multicollinearity among the variables, variance inflation factor (VIF) was calculated and there is no serious problem found.

\begin{tabular}{|c|c|c|c|c|c|}
\hline Adopt SWC & Coef. & Dy/dx & Std.Err. & $\mathbf{Z}$ & t-value \\
\hline Sex & -.175 & -.556 & .652 & -0.85 & 0.393 \\
\hline Education & .182 & .072 & .037 & $4.87^{* * *}$ & 0.000 \\
\hline Experience & 0.032 & 0.013 & 0.011 & $2.77^{* * *}$ & 0.006 \\
\hline Family labor & -.108 & -.044 & .078 & -1.40 & 0.163 \\
\hline Landholding & .327 & .128 & .122 & $2.68^{* *}$ & 0.007 \\
\hline Fragmentation & -.191 & -.070 & .100 & $-1.91^{*}$ & 0.057 \\
\hline TLU & -.054 & -.023 & .036 & -1.49 & 0.135 \\
\hline Credit access & -.338 & -.134 & .231 & -1.46 & 0.144 \\
\hline Slope category & .425 & .139 & .226 & $1.88^{*}$ & 0.061 \\
\hline District category & 1.200 & .346 & .320 & $3.76^{* * *}$ & 0.000 \\
\hline Cooperative distance & 0.005 & -.001 & .041 & 0.12 & 0.902 \\
\hline Perceived Erosion & 0.140 & .046 & .276 & 0.51 & 0.612 \\
\hline DA contact & 0.196 & 0.026 & .065 & $2.98 * * *$ & 0.002 \\
\hline _cons & -1.334 & & .758 & $-1.76^{*}$ & 0.079 \\
\hline \multicolumn{2}{|c|}{ Number of obs. $=202$} & \multicolumn{4}{|c|}{ Prob $>$ chi $2=0.000$} \\
\hline \multicolumn{2}{|c|}{ LR chi2 $(13)=83.35$} & \multicolumn{2}{|c|}{$\begin{array}{l}\text { Log likelihood } \\
\quad=-96.105\end{array}$} & & \\
\hline \multicolumn{2}{|c|}{ Pseudo R2 =0.303 } & & & & \\
\hline
\end{tabular}

Source: own survey data, 2019 


\subsection{RESULTS OF BINARY LOGIT MODEL AND PROPENSITY SCORE ESTIMATION}

Based on matching algorithm result total of thirteen (13) covariates which are used in matching the treated and control were selected and were included in the model and eight of them were found to be significant. The result of logit model on drivers of soil and water conservation practices in Arsi zone was presented as follows (Table 9 ).

As it is expected education has a positive influence on adoption of soil and water conservation activities and significant at 1 percent. This is because of the fact that education is a base for awareness on positive impact of conservation activities on farm productivity. The result is consistent with that of Tesfaye (2017) of sustainable land management, and Gebru et al. (2019) and Beyene etal. (2017) for agro-forestry adoption study. Asfaw and Neka (2017) and Wordofa et al. (2020) also found that education has positive impact on adoption rate of soil and water conservation.

Farm experience was also an important variable that affect adoption of SWC practices positively as expected and significantly at 1 percent probability. This can be explained by the fact that farmers who have long experience in farming may realize the gradual decline in fertility of their farm plots as a result of erosion, and other factors and will be willing for adoption of SWC practices. Result of other studies like Tigist (2010) and Wordofa et al. (2020) farming experience and by Mengstie (2009) and Beyene et al. (2017) age which can be a proxy for farming experience has positive impact on adoption probability of SWC practices. However, result of Anjulo and Mezgebu (2016) shows that age has a negative impact on adoption probability of SWC practices. In other studies, by Asfaw and Asfaw and Neka (2017) and Wordofa et al. (2020) age of respondents which can be proxy variable for experience in farming was significant.

Landholding by household was another variable which is found to be significant in affecting SWC practices adoption in the study area at 95 percent of significance level. The result depicts that as landholding increases, the probability of adopting SWC practices also increases and the result is also in line with other authors like Tigist (2010) and Wordofa et al. (2020), Tesfaye (2017) on sustainable land management, while the result of research by Gebru et al. (2019) shown that landholding was negatively affecting SWC practices.

Land fragmentation which was expressed in terms of number of land plots possessed per a household was also found to be negatively and significantly affecting the probability of SWC adoption at 90 percent level of significance. Slope of the land parcel was also one of the determinant factors that positively influence the adoption rate of SWC practices positively significantly at 90 percent. The more the slope of the land parcel, the greater possibility of adopting the practices. This is an indication for the level of understanding of the farmers that as the slope of their parcel increases, the more they are required to conserve their plots. Other results by Beyene et al. (2017) and Tesfaye (2017) are also in line with this output. 
Another variable which comes out significantly affecting adoption probability was level of vulnerability of districts. Accordingly, districts categorized as vulnerable to different erosion types were found more likely to adopt the practices at 99 percent level of significance. Districts like Inkolowabe which were categorized as severely affected by zonal experts were more adopting relative to others.

Frequency of development agent contacts (visit to DA) was also significant and positive variable in determining adoption probability of SWC and 99 percent level of significance. The result was also similar with other researches like Kassa (2013), Menale et al. (2007), Beyene etal. (2017) and Tesfaye (2017).

\subsection{IMPACT OF ADOPTION OF SOIL AND WATER CONSERVATION PRACTICES}

\section{Choosing Matching A lgorithm and Results of Impact}

Result of matching performance of different estimators (appendix 3) indicated that kernel matching at band width of 0.25 (KBW 0.25) showed best matching quality as it had largest common support which include all sample size, least R-squared (0.092) and reasonably include enough covariates which is 13 out of 16 covariates. In propensity score (pscore) estimation and performing initial balance of the covariate, 6 numbers of blocks were identified that ensured the mean pscore was not different for adopters and non-adopters in each block. The result (appendix 4) also further revealed that before matching, $57.14 \%$ of the covariates pscore estimates show significant but after matching all except one become insignificant. Because of this one covariate was excluded from matching algorithm and the model was run by using thirteen covariates. The balancing efficiency of the estimator was determined by considering the reduction of the mean standardized bias (SB) between the matched and unmatched respondents and equality of means (adopters and non-adopters) was tested using t-test. As shown in Appendix 4, fifth column shows the mean BS before and after matching while sixth column shows the total mean SB reduction obtained by the matching procedure.

The result of analysis (Table 10 ) revealed that the mean impact of adopting SWC practices was positive for all outcome variables. The mean annual gross household income was found to be 6358.86 ETB while yield of major crops (agricultural output per hectare) was 54.81 quintal per hectare. For this particular analysis only major crops of the area which are wheat, barley, maize, sorghum and teff were considered. The mean impact of adoption for soil and water conservation practices on total production (gross production) for abovementioned major crops was 85.35 quintal per annum per households. However, the result also depicted that none of the differences become statistically significant. This can be justified due to the fact that natural resource rehabilitation impact may take some more time to be demonstrated significantly on land productivity. In this regard Abebe and Bekele (2014) and Gatbel et al. (2019) also found the similar result that even though SWC practices have positive impacts on productivity and household income, the differences are not statistically 
significant. However, Kedir (2020) from Ethiopia and Abdulai and Huffman (2014) from Ghana found that adoption of SWC practices have positive and significant impact on household income.

\begin{tabular}{|c|c|c|c|c|c|}
\hline Variable & Treated & Control & Difference & S.E & t-test \\
\hline Total Income & 31772.41 & 25413.55 & 6358.86 & 10177.86 & 0.62 \\
\hline Gross yield & 82.43 & 27.62 & 54.81 & 49.99 & 1.10 \\
\hline Total production & 114.62 & 29.27 & 85.35 & 87.64 & 0.97 \\
\hline
\end{tabular}

Source: own authors computation from survey data, 2019

Moreover, the result from propensity score matching algorithm shows that there are high standard errors for ATT which may be one indication for difference in matching covariance or background difference for land productivity in the zone. In general, given the agro-ecological variability among districts within the zone, there is variability of types of major crops between different districts. Therefore, the statistical comparison of total production and yield among different crops (for instance comparing productivity of wheat and maize) is not as such good and feasible and rather the researcher is more interested in gross annual household income from agricultural products for analysis as a right outcome variable. Therefore, based on households' income difference between adopter and counterfactual group (Table 10 ), one can conclude that adoption of SWC practices can positively influence household income of farmers.

\section{CONCLUSION AND RECOMMENDATIONS}

\subsection{CONCLUSION}

The result revealed that almost all households participated in SWC. All genders categories (male, female and youth) have participated on soil and water conservation activities. However, the survey revealed that adult males (husbands) were more responsible and participated in soil and water conservation campaigns in general. The majority of SWC activities done so far are on individual land parcels but most activities are mobilized by campaign that are organized on individuals holdings each year which are identified prior to the commencement of campaign. The campaign is organized each year since almost ten years after end of main agricultural activities for one to two months based on severity of degradation in the areas. Stone bund, soil bund and cut of drain were the most widely practiced soil and water conservation types. Recently, seedlings of different vegetation are also being distributed even though it is not uniform across the zone.

Different demographic, socioeconomic, and institutional and parcel properties are found to be significantly affecting adoption of soil and water conservation activ- 
ities in the study area. Accordingly, educational background of households, farming experiences, size of landholding, slop of plot, degree of vulnerability of the districts and extension contact are variables which are found to be significantly and positively affected adoption while land fragmentation was significant and negatively influenced adoption of SWC activity. Though it is not statistically significant, SWC adoption has positive impact on productivity and income of $\mathrm{HH}$.

Sustainability of structures is among the main constraints due to fact that there are still some gaps in making SWC activity participatory at every stage and activity handover problem after the end of the campaign. Free grazing and absence of seedlings are among the main constraints of sustainability of SWC activity. Most respondents are aware of natural resource degradation and its impact on their livelihoods. This will create good opportunity in strengthening SWC activities.

\subsection{RECOMMENDATION}

Based on the findings of the research, the following activities are recommended for further adoption and sustainability of soil and water conservation activities.

1. Even though farmers perceive that they are benefiting from SWC activities, there is gap in internalizing the cost and benefits of the activity. Therefore, further awareness and training is needed.

2. Farmers believe that whether they maintain the already done structures or not, SWC activity is their year after year duty. Due to this, they don't worry about sustainability of the structures they have done before. Therefore, there must be an exit strategy which gives accountability to a farmer to maintain the structure done on his/her field.

3. According to the result free grazing is one of the major constraints to SWC sustainability. To overcome such problem, there must be mass community awareness creation and training on activities that could reduce free grazing.

4. In most cases, after construction of physical structures to sustain the structure, covering the structure with grass strips and other vegetation is important. Therefore, availing seedlings for biological intervention of constructed structures should be given a due attention.

5. There are districts which are categorized as vulnerable to different man-made and natural calamities like landslide, erosion and others. These districts are mainly found in Arba-gugu and Dida'a areas. Therefore, these vulnerable districts must be given more attention by both zonal and district development practitioners

\section{REFERENCES}

Abdulai, A., \& Huffman, W. (2014). The Adoption and Impact of Soil and Water Conservation Technology: An Endogenous Switching Regression Application. Land Economics, 90(1), 26-43. Retrieved from https://dx.doi.org/10.3368/le.90.1.26 10.3368/le.90.1.26 
Abebe, Y., \& Bekele, A. (2014). The Impact of Soil and Water Conservation Program on the Income and Productivity of Farm Households in Adama District, Ethiopia. Science, Technology and Arts Research Journal, 3(3), 198-198. Retrieved from https://dx.doi.org/ 10.4314/star.v3i3.32 10.4314/star.v3i3.32

Angima, S. D., Stott, D. E., O'Neill, M. K., Ong, C. K., \& Weesies, G. A. (2003). Soil erosion prediction using RUSLE for central Kenyan highland conditions. Agriculture, Ecosystems \& Environment, 97(1-3), 295-308. Retrieved from https://dx.doi.org/10.1016/ s0167-8809(03)00011-2 10.1016/s0167-8809(03)00011-2

Asfaw, D., \& Neka, M. (2017). Factors affecting adoption of soil and water conservation practices: The case of Wereillu Woreda (District), South Wollo Zone, Amhara Region, Ethiopia. International Soil and Water Conservation Research, 5(4), 273-279. Retrieved from https://dx.doi.org/10.1016/j.iswcr.2017.10.002 10.1016/j.iswcr.2017.10.002

Bekele, S., Okello, J., \& Ratna, V. R. (2009). Adoption and Adaptation of Natural Resource Management Innovations in Smallholder Agriculture. Reflections on Key Lessons and Best Practices. Environment, Development and Sustainability(11), 601-619.

Berhanu, G., Gebremedhin, W., Yigzaw, D., Tilahun, G., \& Worku, T. (2009). Sustainable Land Management through Market-oriented Commodity Development: Case Studies from Ethiopia. Improving Productivity and Market Success (IPMS) of Ethiopian Farmers Project, International Livestock Research Institute (ILRI), Working Paper 21. (pp. 4646). Addis Ababa, Ethiopia.

Bernard, T., Spileman, D. J., Alemayehu, S., \& Eleni, G. (2010). Cooperatives for staple crop marketing: evidence from Ethiopia. IFPRI research monograph., 164.

Berry, L., Olson, J., \& Campbell, D. (2003). Assessing the Extent, Cost and Impact of Land Degradation at the National Level: Findings and Lessons Learned from Seven Pilot Case Studies. Commissioned by Global Mechanism with Support from the World Bank., 6868.

Bruutrup, M., \& Zimmermann, R. (2009). Agriculture as the Potential Engine for African Growth and the Role of NEPAD. CESifo Forum., 29-29.

Bryson, A., Dorsett, R., \& Purdon, S. (2002). The Use of Propensity Score Matching in the Evaluation of Labour Market Policies, Working Paper No. 4, Department for Work and Pensions.

Caliendo, M., \& Kopeinig, S. (2008). Some Practical Guidance for the Implementation of Propensity Score Matching, Discussion Paper No. 1588.

Efd. (2010). Green Accounting Puts Price on Ethiopian Soil Erosion and Deforestation. Retrieved from http//:www.efdinitiative.org/centers/Ethiopia/theenvironment -fordevelopment-imitative

Fao/Wfp. (2005). Report on the Cost-benefit Analysis and Impact Evaluation of Soil and Water Conservation and Forestry Measures in MERET Project. WFP, 176-176.

Gatbel, C., Awdenegest, M., \& Amanuel, S. (2019). Impacts of soil and water conservation practices on livelihood: The case of watershed in Gambela region, Ethiopia. African Journal of Environmental Science and Technology, 13(6), 241-252. Retrieved from https:// dx.doi.org/10.5897/ajest2018.2643 10.5897/ajest2018.2643

Gebru, B. M., Wang, S. W., Kim, S. J., \& Lee, W.-K. (2019). Socio-Ecological Niche and Factors Affecting Agroforestry Practice Adoption in Different Agroecologies of Southern Tigray, Ethiopia.Sustainability, 11(13), 3729-3729. Retrieved from https://dx.doi.org/ $10.3390 /$ su11133729 10.3390/su11133729

Gete, Z. (2000). Landscape Dynamics and Soil Erosion Process Modeling in the Northwestern Ethiopian Highlands. African Studies Series A16. 
Heckman, J., Ichimura, H., Smith, J., \& Todd, P. (1998). Characterizing Selection Bias Using Experimental Data. Econometrica, 66(5), 1017-1017. Retrieved from https://dx.doi .org/10.2307/299963010.2307/2999630

Hurni, H., Berhe, W. A., Chadhokar, P., Daniel, D., Gete, Z., Grunder, M., \& Kassaye, G. (2016). Soil and Water Conservation in Ethiopia: Guidelines for Development Agents., 134, pp-pp.

Kassa, Y. (2013). Determinants of Adoption of Improved Maize Varieties for Male Headed and Female Headed Households in West Harerghe Zone, Ethiopia. International Journal of Economic Behavior and Organization, 1(4), 33-33. Retrieved from https://dx.doi.org/ 10.11648/j.ijebo.20130104.11 10.11648/j.ijebo.20130104.11

Kedir, M. (2020). Impact of Soil and Water Conservation Practice on Income in Chencha District. SNNP of Ethiopia. Civil and Environmental Research, 12(2).

Keele, L. (2010). An overview of rbounds: An R package for Rosenbaum bounds sensitivity analysis with matched data. Retrieved from https://www.researchgate.net/ publication/251969933

Kerr, J., Milne, G., Chhotray, V., Baumann, P., \& James, A. J. (2007). Managing Watershed Externalities in India: Theory and Practice. Environment, Development and Sustainability, 9(3), 263-281. Retrieved from https://dx.doi.org/10.1007/s10668-005-9022-3 $10.1007 /$ s10668-005-9022-3

Kertesz, A. (2009). The Global Problem of Land Degradation and Desertification. Hungarian Geographical Bulletin(1), 19-31.

Kessler, A., \& Stroosnijder, L. (2010). Debating land degradation: Strategy development for Bolivian mountain valleys. Land Degradation \& Development, n/a-n/a. Retrieved from https://dx.doi.org/10.1002/ldr.986 10.1002/ldr.986

Lakew, D., Carucci, V., Asrat, W., \& Ytayew, A. (2005). Community Based Participatory Watershed Development. Ministry of Agriculture and Development.

Land Degradation Strategy. (2010). GEF (Global Environmental Facility.

Menale, K., Pender, J., Yesuf, M., Kohlin, G., Bluffstone, R., \& Mulugeta, E. (2007). Impact of soil conservation on crop production in the Northern Ethiopian Highlands. IFPRI Discussion Paper 00733. Washington, DC., USA: International Food Policy Research Institute.

Menale, K., Precious, Z., John, P., \& Gunnar, K. (2011). Sustainable Agricultural Practices and Agricultural Productivity in Ethiopia: Does Agroecology Matter? Environment for Development Discussion Paper Series., 11-16.

Mengstie, F. A. (2009). Assessment of Adoption Behavior of Soil and Water Conservation Practices in The Koga Watershed, Highlands Of Ethiopia.

Minale, K. (2005). Technology Adoption, Land Rental Contacts, and Agricultural Productivity. PhD Dissertation, Department of Economics and Resource Management. Ås, Norway.

Mitiku, H., Harweg, K., \& Stillhardt, B. (2006). Sustainable Land Management: A New Approach to Soil and Water Conservation in Ethiopia., 305-305.

Mundia, C. N., \& Aniya, M. (2006). Dynamics of landuse/cover changes and degradation of Nairobi City, Kenya. Land Degradation \& Development, 17(1), 97-108. Retrieved from https://dx.doi.org/10.1002/ldr.702 10.1002/ldr.702

Nanpham, T., Yang, D., Kanae, S., T, O., \& Musiakt, K. (2001). Application of RUSLE Model on Global Soil Erosion Estimate. Annual Journal of Hydraulic Engineering, 45.

Reddy, V. R. (2005). Costs of Resource Depletion Externalities: A Study of Groundwater Overexploitation in Andhra Pradesh. India. Environment and Development Economics(10), 533-556.

Rosenbaum, P. R. (2002). Observational Studies (New York: Springer, 2nd edition). Springer. Tamrat, A., \& Ashebir. (2019). Farming System Characterization of Arsi zone: Case of Small- 
Scale Farming. American Journal of Environmental and Resource Economics, 4(1), 1224.

Tamrat, G. (2018). Livestock production system characterization in Arsi Zone, Ethiopia. International Journal of Livestock Production, 9(9), 238-245. Retrieved from https://dx.doi .org/10.5897/ijlp2018.0494 10.5897/ijlp2018.0494

Tekalign, M. (2008). Opening Address to the 9th Annual Conference of the Ethiopian Society of Soil Science.

Tesfaye. (2017). Determinants of Adoption of Sustainable Land Management (SLM) Practices among Smallholder Farmers. Jeldu District.

Tigist, P. (2010).

Wooldridge, M. J. (2002). Econometric analysis of cross section and panel data. Cambridge, Massachusetts London, England: The MIT Press.

Wordofa, M. G., Okoyo, E. N., \& Erkalo, E. (2020). Factors influencing adoption of improved structural soil and water conservation measures in Eastern Ethiopia. Environmental Systems Research, 9(1), 13-13. Retrieved from https://dx.doi.org/10.1186/s40068 -020-00175-4 10.1186/s40068-020-00175-4 


\section{APPENDIX}

Table 1 Conversion factors used to estimate adult equivalent

\begin{tabular}{cccccc}
\hline Age group & Male & Female & Age group 2 & Male 3 & Female \\
$<10$ & 0 & 0 & $17-60$ & 1 & 0.8 \\
$10-13$ & 0.2 & 0.2 & $>60$ & 0.7 & 0.5 \\
$14-16$ & 0.5 & 0.4 & & & \\
\hline
\end{tabular}

Source: Bekele Hundie(2001)

\section{APPENDIX}

Table 2 Conversion factors used to estimate TropicalLivestock Unit (TLU)

\begin{tabular}{cccccc}
\hline Types of animals & TLU & Types of animals & TLU & Types of animal 2 & TLU3 \\
Cow & 1 & Heifers & 0.75 & Donkey & 0.5 \\
Ox & 1 & Calve & 0.4 & Horse/mule & 0.8 \\
Bull & 1 & Sheep/Goat & 0.1 & Camel & 1 \\
\hline
\end{tabular}

Source: (Storck, et al., 1991) and Freeman etal., (1996)

\section{APPENDIX}

Table 3 Matching performance of different estimators

\begin{tabular}{|ccccc}
\hline \multicolumn{2}{c}{ Matching estimator } & \multicolumn{2}{c}{ performance criteria } & \\
\hline & & Balance test* & Pseudo R-square & Matching sample \\
\hline Radius caliper & 0.01 & 12 & 0.17 & 155 \\
& 0.02 & 10 & 0.165 & 192 \\
& 0.03 & 8 & 0.188 & 202 \\
\hline & 0.04 & 9 & 0.188 & 202 \\
\hline Nearest neighbor & 0.05 & 7 & 0.188 & 202 \\
& 1 & 7 & 0.188 & 202 \\
& 3 & 12 & 0.133 & 202 \\
\hline & 4 & 12 & 0.13 & 202 \\
\hline & 5 & 14 & 0.112 & 202 \\
\hline & 0.1 & 12 & 2 & 202 \\
& 0.25 & 14 & 0.092 & 202 \\
\hline
\end{tabular}

Source:Author's computation from survey data 


\section{APPENDIX}

\begin{tabular}{|c|c|c|c|c|c|c|c|}
\hline & Unmatched & Mean & & & & $\%$ reduct & t-test \\
\hline Variable & Matched & Treated & Control & \%bias & bias & t & $p>t$ \\
\hline \multirow[t]{2}{*}{ Sex } & U & .965 & .953 & 6.1 & & 0.43 & 0.667 \\
\hline & M & .965 & .996 & -15.5 & -155.4 & -1.71 & 0.088 \\
\hline \multirow[t]{2}{*}{ Education } & $\mathrm{U}$ & 6.00 & 3.67 & 81.4 & & $5.79 *$ & 0.000 \\
\hline & M & 6.00 & 5.73 & 9.4 & 88.5 & 0.67 & 0.503 \\
\hline \multirow[t]{2}{*}{ Experience } & $\mathrm{U}$ & 24.62 & 20.02 & 39.5 & & $2.76^{*}$ & 0.006 \\
\hline & M & 24.62 & 25.94 & -11.4 & 71.2 & -0.82 & 0.415 \\
\hline \multirow[t]{2}{*}{ Family labor } & $\mathrm{U}$ & 3.04 & 3.28 & -3.21 & & $2.71^{* *}$ & 0.005 \\
\hline & M & 2.84 & 3.18 & -4.3 & 11.25 & 1.01 & 0.98 \\
\hline \multirow[t]{2}{*}{ Landholding } & $\mathrm{U}$ & 2.71 & 1.3423 & 26.8 & & $1.76^{*}$ & 0.079 \\
\hline & M & 2.71 & 1.8355 & 17.1 & 36 & 1.3 & 0.194 \\
\hline \multirow[t]{2}{*}{ No. of Plots } & $\mathrm{U}$ & 2.60 & 2.34 & 17.6 & & 1.22 & 0.223 \\
\hline & M & 2.60 & 2.87 & -18.6 & -5.7 & -1.41 & 0.159 \\
\hline \multirow[t]{2}{*}{ TLU } & $\mathrm{U}$ & 5.29 & 4.6 & 15.4 & & 1.1 & 0.272 \\
\hline & M & 5.29 & 5.2 & 2 & 86.9 & 0.16 & 0.871 \\
\hline \multirow[t]{2}{*}{ Credit Access } & U & .336 & .372 & -7.5 & & -0.53 & 0.59 \\
\hline & M & .336 & .352 & -3.4 & 55.1 & -0.26 & 0.79 \\
\hline \multirow[t]{2}{*}{ District categor } & $\mathrm{U}$ & .301 & .127 & 43.1 & & $2.96^{*}$ & 0.003 \\
\hline & M & .301 & .209 & 23 & 46.7 & 1.62 & 0.107 \\
\hline \multirow[t]{2}{*}{ Coop_distance } & $\mathrm{U}$ & 2.43 & 2 & 14.8 & & 1.03 & 0.306 \\
\hline & M & 2.43 & 1.99 & 15.1 & -2.3 & 1.11 & 0.269 \\
\hline \multirow[t]{2}{*}{ Perceive Erosion } & U & .844 & .755 & 22.3 & & 1.59 & 0.114 \\
\hline & M & .844 & .776 & 17.2 & 23 & 1.33 & 0.184 \\
\hline \multirow[t]{2}{*}{ Erosion Land } & $\mathrm{U}$ & .425 & .688 & -38.7 & & $-2.77^{*}$ & 0.006 \\
\hline & M & .425 & .376 & 7.2 & 81.5 & 0.76 & 0.445 \\
\hline \multirow[t]{2}{*}{ DA_contact } & $\mathrm{U}$ & 3.27 & 2.27 & 61.8 & & $4.39 *$ & 0 \\
\hline & M & 3.27 & 3.51 & -15 & 75.8 & -0.98 & 0.329 \\
\hline \multirow[t]{2}{*}{ Slope_category } & $\mathrm{U}$ & .474 & .302 & 35.6 & & $2.49^{*}$ & 0.014 \\
\hline & & .474 & .414 & 12.5 & 65 & 0.92 & 0.359 \\
\hline
\end{tabular}

\section{APPENDIX}

Household Questionnaire for Adoption and Impact of Soil and Water Conservation Practices on Household Income in Arsi zone, Ethiopia

Date of interview:

Interviewed by (enumerator's name):

\section{Part 1. General Information}

1. Name of the district: ; 2. Name of Kebele:

3. Name of Watershed: 4. Household head name:

5. GPS readings of Village: a) Altitude ; b) Latitude ; c) Longitude:

Part 2: Socio economic characteristics of household heads/respondents 
1. Age of household head/respondent in year:

2. Sex of household head/respondent 1 . Male 0. Female

3. Marital status of household head/respondent:

1. Single 2. Married 3. Divorced 4. Widowed)

4. Educational status of household head/respondent:

1. Illiterate 2. Read and write 3. Informal (religious school)

4. If literate (put years of schooling/grade)

5. Total household size by age and sex

\begin{tabular}{|c|c|c|c|c|c|c|}
\hline S.N & Sex category & $\begin{array}{l}\text { Bellow } 10 \\
\text { years }\end{array}$ & $\begin{array}{l}10-14 \\
\text { years }\end{array}$ & $\begin{array}{l}14-64 \\
\text { years }\end{array}$ & $\begin{array}{l}\text { Above } \\
64 \text { yrs }\end{array}$ & $\begin{array}{l}\text { How many of your children } \\
\text { are at formal school? }\end{array}$ \\
\hline 1 & Male & & & & & \\
\hline 2 & Female & & & & & \\
\hline 3 & $\begin{array}{l}\text { Total } \\
\text { household } \\
\text { size }\end{array}$ & & & & & \\
\hline
\end{tabular}

6. Experience in farming (years).

7. Distance to the nearest main market from residence $(\mathrm{km}) . . . .$. minutes of walking time...........

8. Average single transport cost (per person) to the main market using a car (Birr/person) ...........

9. Distance to the farmer cooperative from residence $(\mathrm{km}) . . . . .$. minutes of walking time..........

10. Distance to main road from residence $(\mathrm{km})$.......minutes of walking time...........

11. Distance to the FTC from residence $(\mathrm{km})$..........minutes of walking time

12. Main roofing material of main residential house. (1. Grass thatch; 2. Iron sheet)

13. What is the major source of your income/livelihood (multiple answer is possible) - - - -?

1. Crop production

2. Small ruminants

3. Cattle production

4. Fruit and vegetable

5. Off/non farming activities

6. Beekeeping

7. Others

14. Relative importance of different sources of income/livelihood for farmers(rank) 


\begin{tabular}{llll} 
S/n & $\begin{array}{l}\text { Major sources of } \\
\text { income/livelihood }\end{array}$ & $\begin{array}{l}\text { Participate }(1=\text { Yes, } \\
0=\text { No) }\end{array}$ & $\begin{array}{l}\text { Estimated annual income } \\
\text { (birr) }\end{array}$ \\
\hline 1 & Grain crop products sales & \\
\hline 2 & Vegetable product sales & \\
\hline 3 & Khat product sales & \\
\hline 5 & Livestock and products sales & \\
\hline 6 & Employed (salaried monthly) & \\
7 & Remittance \\
8 & Daily labour \\
9 & Petty trade \\
10 & Others specify- \\
\hline
\end{tabular}

\section{Land holding during the $2010 / 11$ E.C cropping year}

\begin{tabular}{lll}
\hline Land holding & $\begin{array}{l}\text { Size } \\
\text { (ha) }\end{array}$ & \multicolumn{1}{c}{$\begin{array}{c}\text { Size } \\
\text { (ha) }\end{array}$} \\
\hline $\begin{array}{l}\text { Total land holding (own) } \\
\text { Total cultivated land (annual crop like wheat, barley) }\end{array}$ & $\begin{array}{l}\text { Fallowed land } \\
\text { Covered by } \\
\text { trees }\end{array}$ \\
$\begin{array}{l}\text { Total cultivated land (permanent crops like chat, } \\
\text { coffee) }\end{array}$ & Land rented in \\
\hline $\begin{array}{l}\text { Total cultivated land (annual + permanent crops) } \\
\text { Grazing land }\end{array}$ & Land shared in \\
\hline Homestead land & Land rented out \\
\hline
\end{tabular}

16. Number of plots of land owned:

17. Types of landscape of your farm land:

1. Plain,

2. Gentle slope,

3. steepy slope

18. Cost paid for livestock feed and/or services in 2011 E.C

\begin{tabular}{|c|c|c|c|c|}
\hline No. & Product/service used & Quantity & Unit price/cost & Total cost \\
\hline 1 & Feed purchased & & & \\
\hline 2 & Supplements (minerals) & & & \\
\hline 3 & Veterinary services (in number) & & & \\
\hline 4 & Bull service & & & \\
\hline 5 & Transport & & & \\
\hline 6 & Others & & & \\
\hline
\end{tabular}

\section{Part 4: Access to credit services}

1. Have accessed credit for financing your farm activities for two years?

\section{Yes 2.No}

2. If yes, amount you received in birr?

3. If yes, from where do you received the credit? 
1. Cooperative

2. Micro Finance

3. Local money lenders

4. Others specify:

4. If yes, for what purposes did you received the credit?

5. Have you received credit to finance your SWC activity for the last five years?

1. Yes 2. No

6. If yes, amount you received in birr? , and sources

7. If no, what are your sources of finance to invest on SWC practices?

1. Own finance

2. No need to invest on SWC

3. Others, Specify,

\section{Part 8: Farmers' Perception of the impact of soil erosion/land degradation}

1. Do you think soil erosion is a problem for your farmland? (tick)

1. Yes 2. No

2. If yes, how do you perceive the level of soil erosion in your farm land? (tick)

1. Very severe

2. Severe

3. Less severe

3. If yes, how much of your farm land affected by erosion in hectare?

4. If yes, how do you perceive the severity of soil fertility decline of your farm lands?

1. Very severe

2. Severe

3. Less severe

5. What do you think about the major cause of soil erosion for your farm land (rank)?

1. Deforestation

2. Overgrazing

3. Poor agricultural practices

4. Over cultivation

5. Cultivation of steep slope lands

6. Excessive rainfall

6. What do you think about the major cause of soil fertility decline for your farm land (tick)?

1. Soil erosion

2. Limited use of fertilizers

3. Land is cultivated continuously

4. Lack of use conservation practices

5. Lack of land fallowing

6. If others (specify): 
7. What do you think is the consequence of soil erosion? (Rank)

\begin{tabular}{|c|c|c|}
\hline No. & Consequences of soil erosion/land degradation 1 . Yes 0 . No & Give rank \\
\hline 1 & Land productivity decline & \\
\hline 2 & Soil fertility declined & \\
\hline 3 & Change in type of crops grown & \\
\hline 4 & Abandonment of land from crop production & \\
\hline 5 & Land preparation becomes difficult & \\
\hline 6 & Reduces farm size & \\
\hline 7 & Gully and sandy soil formation & \\
\hline 8 & Soil depth decreased & \\
\hline 9 & Water holding capacity of land declined & \\
\hline
\end{tabular}

PART 10: Community Participation on Campaign of SWC practices

1. Do you participate on soil and water conservation campaign organized so far?

1. Yes 0 . No

2. If yes, for how many years?

3.If No, why?

4. If you participate on SWC activities, is it on project based?

1. Yes 0. No

5.If it is project based, please name the project.

6.When does the project started (year project started) ?

7.What support does the project give to the SWC activities?

1. training participants

2. Financial support

3. Material support

4. Provide food to beneficiaries

8. How do you participate on SWC in the watershed?

9. The land on which you conduct SWC activities are:

1. Communal

2. Individual's

10. Is there area closure in your area?

1. Yes 0 . No

11. If there is area closure, did it get rehabilitate?

1. Yes 0 . No

12. If it rehabilitated, how did you get benefit from it?

1. Use water from spring generated

2. Use cut-carry grass for livestock

3. Use beekeeping in the area

4. Use wood for house construction and firewood

5. Others(specify)

13. Do you think that the SWC practices have an impact on your household Income and productivity?

1. Yes 0 . No 
14. How do you rate extension services on SWC?

1. Very poor

2. Poor

3. Medium

4. Good

5. Very good

15. What are the weaknesses of SWC campaign by the government each year?

1. No training

2. No material/seedlings

3. No participation on planning

4. No accountability after work

16. What is the productivity five major crops?

\begin{tabular}{llll}
$\begin{array}{l}\text { No. List of three major } \\
\text { crops grown }\end{array}$ & $\begin{array}{l}\text { Yield per hectare in 2003 E.C } \\
\text { (before SWC) }\end{array}$ & $\begin{array}{l}\text { Yield in 2010/11 per hectare } \\
\text { (after SWC done) }\end{array}$ \\
\hline 1. & & \\
\hline 2. & .............
\end{tabular}

17. What is the income from the following Activities on area closure? (To be filled for both groups)

\begin{tabular}{|c|c|c|c|}
\hline No. & Sources of income & $\begin{array}{l}\text { Estimated Income amount } \\
\text { in } 2004 \text { E.C (before SWC } \\
\text { done) }\end{array}$ & $\begin{array}{l}\text { Estimated Income amount } \\
\text { in } 2011 \text { E.C (after SWC } \\
\text { done) }\end{array}$ \\
\hline 1 & $\begin{array}{l}\text { Use water from spring } \\
\text { generated }\end{array}$ & & \\
\hline 2 & $\begin{array}{l}\text { Use cut-carry grass for } \\
\text { livestock }\end{array}$ & & \\
\hline 3 & $\begin{array}{l}\text { Use beekeeping in the area } \\
\text { closure }\end{array}$ & & \\
\hline 4 & $\begin{array}{l}\text { Use wood for house } \\
\text { construction and firewood } \\
\text { from area closure }\end{array}$ & & \\
\hline 5 & $\begin{array}{l}\text { Employed as guard for area } \\
\text { closure }\end{array}$ & & \\
\hline
\end{tabular}

Who participate on SWC activities in your household? (Multiple answer possible)

1. Husband 2. Wife 3. Boys 4. Daughter 5. Hired laborer

Part 5: Crop production and marketing

1. Crop production and income from crops in 2010/11 cropping season

\begin{tabular}{|c|c|c|c|c|c|c|c|c|}
\hline $\begin{array}{l}\text { Crop } \\
\text { types } \\
\text { grown }\end{array}$ & $\begin{array}{l}\text { Cultivated } \\
\text { Area (ha) }\end{array}$ & $\begin{array}{l}\text { Total quantity } \\
\text { produced }(\mathrm{kg})\end{array}$ & $\begin{array}{l}\text { Quantity } \\
\text { consumed } \\
\mathrm{kg})\end{array}$ & $\begin{array}{l}\text { Quantity } \\
\text { saved for } \\
\text { seed }(\mathrm{kg})\end{array}$ & $\begin{array}{l}\text { Did you sell? } \\
1 \text {. Yes } 0 . \text { No }\end{array}$ & $\begin{array}{l}\text { Quantity } \\
\text { sold (kg) }\end{array}$ & $\begin{array}{l}\text { Average selling } \\
\text { price (birr/kg }\end{array}$ & $\begin{array}{l}\text { Who sold? } \\
1=\text { Men, } 2= \\
\text { women }\end{array}$ \\
\hline \multicolumn{9}{|l|}{ Wheat } \\
\hline \multicolumn{9}{|l|}{ Barley } \\
\hline $\begin{array}{l}\text { Maize } \\
\text { etc }\end{array}$ & & & & & & & & \\
\hline
\end{tabular}


Crop production and input use during 2010/11 E.C cropping season for three major crops in terms of land allocation

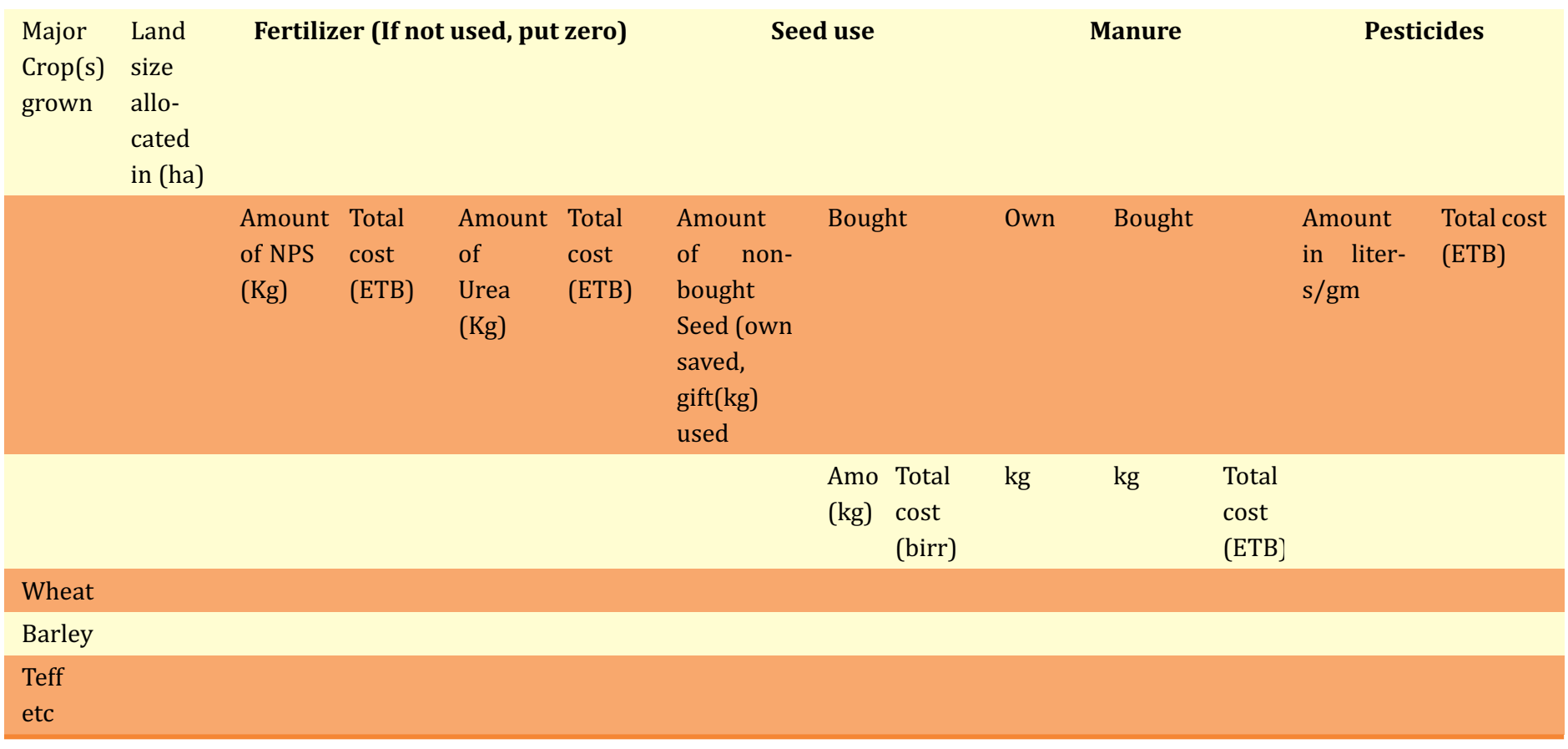

Part 6: Livestock production and marketing

1. Livestock type, number kept and their values in 2010/11 E.C cropping season Part 7: Off/non-farm activities

1. Do you or any member of your family have off-farm/non-farm job? 1 . Yes 2. No

2. If yes, indicate the type of off/non-farm activities and annual income for the year 2010/11 


\begin{tabular}{|c|c|c|c|c|c|c|c|}
\hline Livestock type & $\begin{array}{l}\text { Number of live- } \\
\text { stock owned } \\
\text { at end of } 2011 \\
\text { cropping sea- } \\
\text { son (including } \\
\text { bought ones) }\end{array}$ & 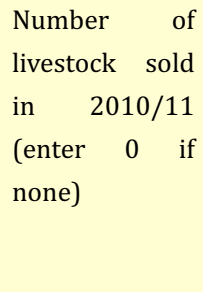 & $\begin{array}{l}\text { If you would } \\
\text { sell, how much } \\
\text { would you } \\
\text { receive from } \\
\text { the sale? (ETB) } \\
\text { (take average) }\end{array}$ & $\begin{array}{l}\text { Average lactat- } \\
\text { ing period }\end{array}$ & $\begin{array}{l}\text { Average daily } \\
\text { milk yield per } \\
\text { animal (liters)/ } \\
\text { honey(kg)(no.) }\end{array}$ & $\begin{array}{l}\text { Total pro- } \\
\text { duction milk } \\
\text { (liters) \& honey } \\
\text { production per } \\
\text { beehive (kg) } \\
\text { egg produc- } \\
\text { tion(number) }\end{array}$ & $\begin{array}{l}\text { Amount earned } \\
\text { per annum }\end{array}$ \\
\hline
\end{tabular}

\section{Cattle}

1. Indigenous milking

cows

2. Cross-bred milking

cows

3.Exotic milking cows

4. Non milking cows

(mature)

5. Trained oxen

6. Bulls

7. Heifers

8. Calves

Goats

9. Adult male goats

10.Young male goats

11.Young female goats

Sheep

13. Male sheep

14. Mature female sheep

15. Young male sheep

16. Young female

sheep

Other livestock

17. Mature trained

donkeys

18. Young donkeys

19. Horses

20. Mules

21. Mature chicken

22. Local Bee hives

23.Modern Bee hives

Part 9: Farmers' Perception of the Impact of Soil and Water Conservation

\section{Measures}

1. Did you use soil and water conservation practices on your farm land? 1 . Yes 2. No

2. If no for the question no.1 please pass to question no. 12 
3. If yes for the ques. no. 1 what type of SWC practices used on your farm plots? 1. Traditional 2. Improved 3. Both

4. If improved SWC technologies used on your farm land, fill the following table

$\begin{array}{lllll}\text { S/N } & \begin{array}{l}\text { Off/non-farm } \\ \text { activities }\end{array} & \begin{array}{l}\text { 1. Yes } \\ \text { 0. No }\end{array} & \begin{array}{l}\text { Payment mode } \\ \text { 1. In kind 2. Cash }\end{array} & \begin{array}{l}\text { Total annual } \\ \text { income(birr/annual) }\end{array} \\ 1 & \text { Livestock trading } & & & \\ 2 & \text { Grain trading } & & \\ 3 & \begin{array}{l}\text { Vegetable and fruit } \\ \text { trading }\end{array} & & \end{array}$

$\begin{array}{lllllll}\text { Type of Soil } & \text { what type of } & \text { For } & \text { Improved } & \text { Which type of } & \text { Which type of } \\ \text { and water } & \text { improved SWC } & \text { how many } & \text { SWC } & \text { improved SWC } & \text { improved SWC } \\ \text { conservation } & \text { technologies used } & \text { Years did you } & \text { con- } & \text { technologies are easy } & \text { practice is effective } \\ \text { (SWC) } & \text { on your farm? } & \text { use it? } & \text { structed } & \text { to implement? } & \text { in your farm plots? } \\ \text { technologies } & \text { (1. Yes } 0 . \text { No) } & \text { (Number of } & \text { by** } & \text { (Rank:1,2,3,4,5) } & \text { (tick) } \\ & & \text { years) } & & & \end{array}$

\section{Stone bund}

\section{Soil bund}

3. Stone faced soil bund

4. Fanyajuu

5. Cut-off drain

6. Check-dam

\section{Terracing}

8. Contour ploughing

9. Grass-strip

10. Farm

forestry

11. Integrated

SWC

11. Others, specify

12.

Problems related to SWC technologies*

1. Not effective to reduce erosion 1 . Community campaign

2. Labour intensive 2. PSNP/other projects

3. Requires frequent maintenance 3 . Farmers themselves

4. Difficult to implement

5. Take land out of production

6. Difficult to turn oxen

5. If improved SWC practices used on your farm land, fill the following table 


\begin{tabular}{llllll}
$\begin{array}{l}\text { Types of } \\
\text { improved SWC } \\
\text { practices built in } \\
\text { on your farm } \\
\text { land }\end{array}$ & $\begin{array}{l}\text { Area of } \\
\text { land } \\
\text { devel- } \\
\text { oped in } \\
\text { meter }\end{array}$ & $\begin{array}{l}\text { Number of } \\
\text { plots SWC } \\
\text { practices built } \\
\text { on the farm } \\
\text { land }\end{array}$ & $\begin{array}{l}\text { Types of } \\
\text { improved SWC } \\
\text { practices built in } \\
\text { on your farm } \\
\text { land }\end{array}$ & $\begin{array}{l}\text { Area of } \\
\text { land } \\
\text { devel- } \\
\text { oped in } \\
\text { meter }\end{array}$ & $\begin{array}{l}\text { pumber of } \\
\text { practices built } \\
\text { on the farm }\end{array}$ \\
$\begin{array}{l}\text { Soil bund } \\
\text { Cut-off drain }\end{array}$ & & Fanya juu & \\
Check-dam & & Farm forestry & \\
Terraces & & Grass strip & \\
\hline
\end{tabular}

6. If you are using improved SWC technologies/practices, what factors do you consider in constructing SWC structures on your farm land?

1. Land size 2. Soil characteristics 3 . Labor availability 4 . Soil fertility status

5. Steepness of the slope 6. Intensity of rainfall 7. Availability of construction material

8. Others, specify:

7. How do you compare the problem of soil erosion in your farm land after intervention of improved SWC technology/practice?

1. Aggravated 2. Reduced 3. No change 4. I do not know

8. Did you have plots where improved SWC structures were built by food for work or by any other community participation in the past? 1 . Yes 2 . No

9. If yes, what is the present condition of the structures?

1. Partially removed 2 . Completely removed 3 . Reconstructed 4. Retained

10. Which type of structures did you remove?

1. Soil bund 2. Stone bunds 3. Check-dam 4. Others:

11. How do you perceive the importance of SWC technologies?

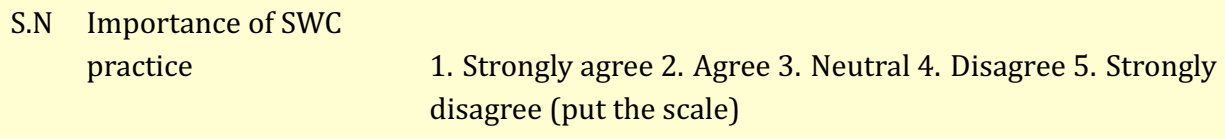

\begin{tabular}{|ll|}
\hline 1 & Improving soil fertility \\
\hline 2 & $\begin{array}{l}\text { Improving vegetation } \\
\text { cover }\end{array}$ \\
\hline 3 & Improving crop yield \\
\hline 4 & Improving income \\
\hline 5 & $\begin{array}{l}\text { Alleviate food } \\
\text { shortage }\end{array}$ \\
\hline 6 & $\begin{array}{l}\text { Improving water } \\
\text { availability }\end{array}$ \\
\hline 7 & Soil depth increased \\
\hline 8 & Reducing runoff \\
\hline
\end{tabular}

12. If you removed constructed SWC structures from your farmland, why? 1. I think it wastes my farmland 2. I didn't see its advantages 3. It was removed by erosion or ... 4. Damaged by others livestock 
5. Others (specify)

13. If you use traditional conservation practice used on your farm land, fill the following table

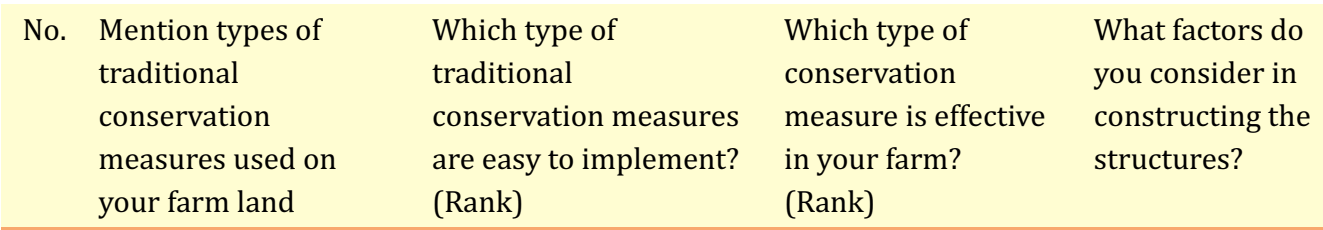

$1 \quad$....

PART 10: Community Participation on Campaign of SWC practices

18. Do you participate on soil and water conservation campaign organized so far? 1. Yes 0 . No

19 If yes, for how many years?

20. If No, why?

21. If you participate on SWC activities, is it on project based? 1. Yes 0. No

22 . If it is project based, please name the project.

23. When does the project started (year project started) $?$

24. What support does the project give to the SWC activities? 1. training participants

2. Financial support 3. Material support 4. Provide food to beneficiaries

25. How do you participate on SWC in the watershed?

26. The land on which you conduct SWC activities are: 1. Communal 2. Individual's

27. Is there area closure in your area? 1 . Yes 0 . No

28. If there is area closure, did it get rehabilitate? 1 . Yes 0 . No

29. If it rehabilitated, how did you get benefit from it? 1. Use water from spring generated 2. Use cut-carry grass for livestock 3. Use beekeeping in the area 4 . Use wood for house construction and firewood

5. Others(specify)

30. Do you think that the SWC practices have an impact on your household Income and productivity?

1. Yes 0 . No

31. How do you rate extension services on SWC?

1. Very poor 2. Poor 3. Medium 4. Good 5. Very good

32. What are the weaknesses of SWC campaign by the government each year? 1. No training 2. No material/seedlings 3. We do not participate on planning 4 . No accountability after work

33. What is the productivity five major crops?

\begin{tabular}{llll} 
No. List of three major & $\begin{array}{l}\text { Yield per hectare in 2003 E.C } \\
\text { (before SWC) }\end{array}$ & $\begin{array}{l}\text { Yield in 2010/11 per hectare } \\
\text { (after SWC done) }\end{array}$ \\
\hline 1. & & \\
\hline 2. & .............
\end{tabular}


34. What is the income from the following Activities on area closure? (To be filled for both groups)

No. Sources of income

1 Use water from spring generated

2 Use cut-carry grass for livestock

3 Use beekeeping in the area closure

4 Use wood for house construction and firewood from area closure

$5 \quad$ Employed as guard for area closure

35. Who participate on SWC activities in your household? (Multiple answer possible)

1. Husband 2. Wife 3. Boys 4. Daughter 5. Hired laborer

\section{Part 11: Institutional support}

3. Agricultural extension services participation

\begin{tabular}{|c|c|c|c|}
\hline No. & Description & Response & Remark \\
\hline 1 & $\begin{array}{l}\text { Frequency of contact with DAs per } \\
\text { month }\end{array}$ & & _times \\
\hline 2 & $\begin{array}{l}\text { Have ever read of extension materi- } \\
\text { als? }\end{array}$ & & 1. Yes 0 . No \\
\hline 3 & Have you ever been model farmer? & & 1. Yes 0 . No \\
\hline 4 & $\begin{array}{l}\text { Do you listen to radio on agricultural } \\
\text { program? }\end{array}$ & & 1. Yes 0 . No \\
\hline 5 & $\begin{array}{l}\text { Have you participated on SWC prac- } \\
\text { tices? }\end{array}$ & & 1. Yes 0 . No \\
\hline 6 & $\begin{array}{l}\text { Have you participated on demon- } \\
\text { stration on any agricultural matters } \\
\text { (crop/livestock)? }\end{array}$ & & 1. Yes 0 . No \\
\hline 7 & $\begin{array}{l}\text { Have you participated on Natural } \\
\text { resource conservation? }\end{array}$ & & 1. Yes 0 . No \\
\hline 8 & $\begin{array}{l}\text { How far is the DA site from your home } \\
\text { (-hrs) }\end{array}$ & & Walking hrs \\
\hline
\end{tabular}

